\title{
The Effect of Capital Structure and Sales Growth on Company Profitability and Value in the Cosmetics Manufacturing and Household Needs Manufacturing Companies
}

\author{
Ni Putu Erlin Pramesti ${ }^{1}$, Putu Ngurah Suyatna Yasa ${ }^{2}$ and Ni Luh Anik Puspa Ningsih ${ }^{3}$ \\ Magister of Management, Postgraduate Program, Universitas Warmadewa, Denpasar, Bali- \\ Indonesia \\ *kinapuspa168@gmail.com
}

\begin{tabular}{|l|}
\hline \multicolumn{1}{|c|}{ Published: 30/09/2021 } \\
\hline How to cite (in APA style): \\
Pramesti, N. P. E., Yasa, P. N. S., \& Ningsih, N. L. A. P. (2021). The Effect of Capital Structure and Sales Growth on \\
Company Profitability and Value in the Cosmetics Manufacturing and Household Needs Manufacturing Companies. Jurnal \\
Ekonomi dan Bisnis Jagaditha, 8(2), 187-193. doi: https://doi.org/10.22225/jj.8.2.2021.187-193 \\
\hline
\end{tabular}

\begin{abstract}
Company value is very important for a company, because the company's value reflects the company's performance which will be associated with stock prices, where the higher the stock price, the higher the value of the company. With a high company value will give a good signal to investors that the company's financial performance is increasing. This study aims to determine the effect of capital structure and sales growth on profitability and firm value. The population in this study is cosmetics and household needs manufacturing companies listed on the IDX. Determination of the sample is done by a purposive sampling method of judgment sampling type and based on predetermined criteria; the number of samples is 5 companies manufacturing cosmetics sub-sectors and household needs. This study uses secondary data obtained from the Indonesia Stock Exchange in 2008-2018. Testing the hypothesis of the study used descriptive statistical test techniques and path analysis test with SPSS (Statistical Product and Service Solutions) application tools. The results showed that: 1) Capital structure has a positive and significant effect on profitability 2) Sales growth has a negative and not significant effect on profitability 3) Capital structure has a positive and significant effect on firm value 4) Sales growth has a positive and significant effect on firm value 5) profitability has a positive and significant effect on firm value 6) Capital structure is able to influence the value of the company through profitability 7) Sales growth is not able to affect the value of the company through profitability.
\end{abstract}

Keywords: Capital Structure; Firm Value; Profitability; Sales Growth

\section{INTRODUCTION}

The rapid flow of information currently supports the development of this country. This development is marked by the emergence of many state-owned and private companies in which these companies are getting bigger and growing, as well as becoming one of the production activity units that manage the resource economy to provide goods and services for the community. One of the growing consumer goods is cosmetics. The condition of the development of the cosmetics business field in Indonesia is currently experiencing very rapid growth, from the latest data on the cosmetics industry in the Ministry of Industry (2018) states that the last 1 year sales of cosmetic products increased to an average of $20 \%$ per year for one company every one month. This shows that the use of cosmetics in Indonesia is in great demand. Company value is a measure of the success of company management in past operations and prospects in the future to convince shareholders, (Salvatore, 2005). Company value is very important because it reflects the performance of the company which can affect investors' perception of the company. Investors in making funding decisions in the capital market 
need information about stock valuations. There are three types of valuation related to shares, namely: book value, market value, and Hartono's intrinsic value (2013:179). One of approach in determining the intrinsic value of a stock is the price book value (PBV). PBV or ratio between price per book value is the relationship between price per share and book value per share.

Based on capital structure theory, if the position of the capital structure is above the optimal capital structure target, then any additional debt will reduce the value of the company, (Sartono, 2012). Determination of optimal capital structure targets is one of the main tasks of company management. Capital structure is the proportion of funding with debt (debt financing) of the company, namely the leverage ratio (leverage) of the company, (Sartono, 2012). Sales growth is also used to forecast the company's future prospects. The increasing sales growth will increase the company's revenue and help the company to be able to expand its business, (Dramawan, 2015). Profitability is the company's ability to make a profit in relation to sales, total assets and own capital. Thus, long-term investors will be very interested in this profitability analysis, for example shareholders will see profits that will actually be received in the form of dividends, (Sartono, 2012).

Some related studies have been conducted previously which concerned with the capital structure. (Hamidah et al., 2016) in their study conducted the effect of profitability, liquidity, sales growth, operating leverage and tangibility on capital structure: evidence from manufacture firm listed on Indonesia Stock Exchange in 2011-2014. The result of this study showed that profitability and liquidity have a negative and significant effect on capital structure. Sales growth and operating leverage have a positive but not significant effect on capital structure. Tangibility has a negative and not significant effect on capital structure. Meanwhile, a study about the influence of firm size, asset structure and the profitability toward the capital structure in automotive sector companies listed on the Indonesia stock exchange (BEI) conducted by (Djazuli et al, 2019) revealed that there was no significant influence of firm size to capital structure. There was a significant influence of asset structure on capital structure. There was no significant influence of profitability on capital structure. There was a significant influence of firm size, asset structure and profitability toward the capital structure. A similar study has also been conducted by (Marlina et al., 2020) which examine the effect of liquidity, profitability and sales growth on capital structure. The result of this study showed that (1) the liquidity stated by the Current Ratio has no significant effect on the Capital Structure. (2) profitability stated by Return On Equity has a significant positive effect on Capital Structure, (3) sales growth stated by Sales Growth has no significant positive effect on Capital Structure.

Based on the explanation and the previous empirical gap described above, the relationship between Capital Structure and Sales Growth on Profitability and Firm Value, there is not always a significant positive effect, there is also a non-significant negative effect. Hence, this study aims to determine the effect of capital structure and sales growth on profitability and firm value.

\section{CONCEPT AND HYPOTHESIS}

The company is an organization that combines and organizes various resources with the aim of producing goods and services for sale (Salvatore, 2005). Company value is a measure of the success of company management in past operations and prospects in the future to convince shareholders indicated by ratios such as market book value and Price Earning Ratio (PER), (Machfoedz, 2008). According to (Sartono, 2001), "Capital structure is a balance of the amount of short-term debt that is permanent, long-term debt, preferred shares and ordinary shares". According to (Margaretha, 2011), a company's capital structure is a specific combination of equity and long-term debt that a company uses to fund its operations. Meanwhile, according to (Subramanyam \& Wild, 2014), capital structure is the funding of equity and debt in a company which is often calculated based on the relative magnitude of various funding sources.

Sales Growth is an increase in sales from year to year or from time to time. Companies that have high sales growth rates will need more investment in various asset elements, both fixed assets and current assets, (Kesuma, 2009). The sales growth reflects the ability of the company from time to time. The higher the level of sales growth of a company, the company has successfully carried out its strategy, (Widarjo \& Setiawan, 2009). Sales growth is a change in sales per year. High sales growth gives an indicator of the company 
concerned can increase the growth of the company and is expected to increase profits generated, (Hatta, 2002). Profitability is the company's ability to make a profit in relation to sales, total assets and own capital. Thus, long-term investors will be very interested in this profitability analysis. For example, shareholders will see profits that will actually be received in the form of dividends, (Sartono, 2012). Profitability is a picture of management performance in managing a company, (Wiagustini, 2010).

\section{Capital Structure and Profitability}

The higher the ratio of debt to equity, the greater the risk faced and investors will ask for a higher level of profit. Previous research conducted by (Dery, 2014), (Limbong \& Chabachib, 2016) shows that capital structure has a positive and significant effect on profitability. (Kusumajaya, 2011) shows that capital structure has a positive and significant effect on profitability. Based on the above research it can be said that the high use of debt will reduce the profitability of the company, and then the hypothesis can be formulated as follows:

H1: Capital structure has a positive and significant effect on profitability.

\section{Sales Growth and Profitability}

High sales growth shows an increase in revenue obtained by the company from product sales in the activities of the company. Sales growth from the previous year on a regular basis can be used to predict sales growth in the coming year. In a previous study by (Limbong \& Chabachib, 2016) it was found that sales growth had a positive and significant effect on profitability. Research also conducted by (Pantow et al, 2015) found that company growth had a positive effect on profitability. Based on these studies it can be said that sales growth is indicated to be positive will increase profitability. Then the hypothesis can be formulated as follows:

H2: Sales growth has a positive and significant effect on profitability.

\section{Capital Structure and Growth Value}

In a previous study conducted by (Limbong \& Chabachib, 2016) argues that capital structure has a positive effect on firm value. According to Dhani \& Utama's research (2017) explains that capital structure has a positive effect on company value. Therefore maximizing shareholder wealth requires a perfect combination of debt and equity. Based on the above research it can be said that the combination of debt and equity has an influence on the value of the company with the assumption that capital structure in the use of debt will reduce the value of the company. Then the hypothesis is formulated as follows:

H3: Capital structure has a positive and significant effect on firm value.

\section{Sales Growth and Company Value}

Companies that have high sales growth rates will attract investors and are expected to influence the movement of stock prices so that the value of the company increases (Murhadi, 2008). Previous research conducted by (Dhani \& Utama, 2017) found that sales growth had a positive effect on firm value, and research from (Pantow et al, 2015) showed that sales growth had a positive effect on firm value. Based on the above research it can be said that sales growth can increase company value. Then the hypothesis is formulated as follows.

H4: Sales growth has a positive and significant effect on firm value.

\section{Profitabilitas and Company Value}

Return on equity is a very important ratio for the owner of the company (the common stockholder). Previous research conducted by Fibriyanto (2015) found that profitability had a positive and significant effect on firm value. This research is also supported by Dewi \& Sudiartha (2017) showing that profitability has a positive effect on firm value. Based on the above research it can be said that an increase in the profitability of a company will have an impact on increasing the price of shares allocated to shareholders that can increase the value of the company. Then the hypothesis can be formulated as follows:

H5: Profitability has a positive and significant effect on firm value.

\section{Profitability and Capital Structure of Company Value}

According to research from Chowdhury \& Paul Chowdhury (2010), arguing that forcing the shareholder wealth into wealth requires a perfect combination of debt and equity. According to Limbong \& Chabachib (2016) said that capital structure has a positive effect on company value and according to Shubita \& Alsawalhah (2012) found that an increase in debt position is associated with a decrease in profitability. Thus, the higher the debt, the lower the profitability. An increase in debt in the capital structure is related to the 
profitability of a company so the following hypothesis can be formulated:

H6: Profitability is able to mediate the capital structure of the firm's value

\section{Profitability, Sales Growth on Company Value}

All profitability has a strong positive relationship with how sales growth. Research from Pantow et al. (2015) found that sales growth had a significant positive effect on profitability. According to Limbong \& Chabachib (2016) found that sales growth has a significant effect on profitability. Based on the description, this means that any sales growth will affect the company's profitability. Then the hypothesis can be formulated as follows:

H7: Profitability is able to mediate the growth of sales to the value of the company

\section{METHOD}

This research was conducted at the Indonesia Stock Exchange by processing complete data on the cosmetics sub-sector manufacturing companies and household needs for the period 2008 to 2018 accessed through www.idx.co.id. The research model used is quantitative by using the final path mode.

Final Pathway Model

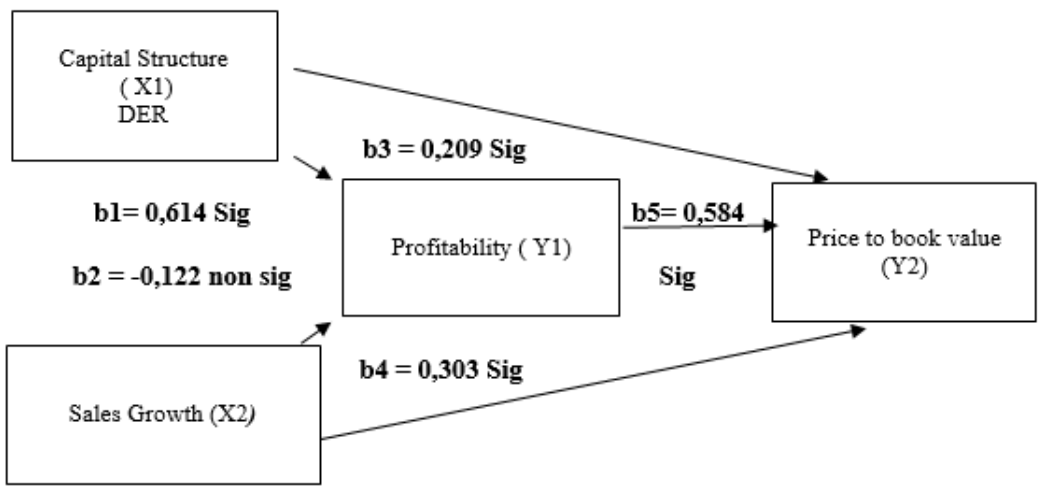

Figure 1

Path Chart Influence of Capital Structure and Sales Growth on Company Profitability and Value

The model in Figure (1) can be expressed in the form of an equation so as to form a system of equations. Some of these equation systems call the simultaneous equation system, or some call the structural model. The criterion used in this study was to publish financial reports in a row during the study period in the manufacturing companies of the cosmetics sub -sector and household needs in 2008-2018, which amounted to 6 companies. The analysis technique used in this study is a descriptive statistical test, classic assumption test, and path analysis test. The SPSS application program is used to assist in analyzing data in this study.

\section{RESULT AND DISCUSSION}

Based on the results of hypothesis testing, it was found that capital structure has a positive and significant effect on profitability. This means that the cosmetics sub -sector manufacturing companies and household needs on the Stock Exchange in 2008-2018 with the addition of the use of debt by the company can increase net income, the ratio used is DER (Debt to Equity Ratio) indicated by the amount of debt in the capital structure can increase the company's operational activities which have an impact on increasing profitability. These findings are consistent with previous studies from Kusumajaya (2011), Dery (2014), Pantow et al. (2015) and Limbong \& Chabachib (2016) who found that capital structure as measured by the debt to equity ratio had a positive and significant effect on profitability. This also means that if there is an increase in the company's decision to add debt it will affect the company's profitability which will increase.

Based on the results of hypothesis testing, it can be seen that sales growth has a negative and not significant effect on profitability. This study found that sales growth has increased and company profitability has declined and has not been able to increase profitability in the cosmetics sub-sector manufacturing companies and household needs in 2008-2018. However, in this study, sales growth is not able to increase profitability because the costs incurred by companies experience changes in fluctuations in changes in sales growth. So that sales growth cannot increase 
profitability. These findings are not consistent with previous studies from Limbong \& Chabachib (2016), Dramawan (2015) and Pantow et al. (2015) who found that sales growth had a positive and significant effect on profitability. This means that companies that make high investments will be a benchmark of company growth in the future. This information is a sign for long-term investors, which can affect investors' perceptions of the company's financial performance, namely increased profitability.

Based on the results of hypothesis testing, it can be seen that the capital structure has a positive and significant effect on firm value in the cosmetics sub-sector manufacturing companies and household needs on the Indonesia Stock Exchange in 2008-2018. This research can be interpreted that the addition of debt by a company to expand the business will increase the stock price of the company. The increase in the value of the company due to an increase in the amount of debt (debt is still below its optimal point) is caused by the company's management using the debt for business expansion of the company. These findings are consistent with research from Limbong \& Chabachib (2016), Kusumajaya (2011), Puspita (2011), Ugwuanyi (2012), Hermuningsih (2012), Dery (2014) and Dhani \& Utama (2017) find that capital structure has a positive and significant effect on the value of the company.

Based on the results of hypothesis testing, it can be seen that sales growth has a positive and significant effect on firm value in the cosmetics sub-sector manufacturing companies and household needs on the Stock Exchange in 2008-2018. Sales growth shows the development of the company. A company that has high sales growth reflects the development of the company is high. According to Brigham \& Houston (2001) companies with relatively stable sales levels if they obtain more loans and bear higher fixed costs, companies with fast growth rates must use more external capital by considering the floating costs incurred. The results of research from Sari \& Abundanti (2014), Putri (2020), and Dhani \& Utama (2017) found that sales growth had a positive and significant effect on firm value.

Based on the results of hypothesis testing, it can be seen that profitability has a positive and significant effect on firm value in the cosmetics sub-sector manufacturing companies and household needs in 2008-2018. Hypothesis testing can be interpreted that an increase in net income can increase profitability as represented by the variable ROE (return on equity), because of the denial of profitability, the company's stock price increases thereby increasing PBV (Price to Book Value). Signaling theory explains the results of the study, where investors will increase demand for shares if the profitability of the company increases, and on the other hand also increases the value of the company. Consistent findings from Kusumajaya (2011), Puspita (2011), Hermuningsih (2012), Fibriyanto (2015) and Dewi \& Sudiartha (2017) show that the Return on Equity (ROE) variable has a positive and significant effect on price to book value.

Based on the results of hypothesis testing, it can be seen that profitability is able to mediate the influence of capital structure with firm value, there are companies manufacturing cosmetics sub-sectors and household needs. The results of this analysis illustrate that the capital structure used by companies as a benchmark of profitability is able to have a better impact on achieving corporate value compared to the direct impact of capital structure on firm value. In a further study it can be said that the direct effect of capital structure on firm value is greater than the indirect effect through profitability mediation, thus companies can increase the value of their companies by increasing debt, where increasing debt can also increase profitability which can indirectly increase the value company with higher. To increase the value of the company, this capital structure must absolutely go through profitability. The findings of this study suggest that an increase in capital structure can cause firm value to increase without first seeing an increase in profitability in cosmetics companies and household needs.

Based on the results of hypothesis testing, it can be seen that profitability is not able to mediate the effect of sales growth with firm value on the cosmetics sub-sector manufacturing companies and household needs. In further studies it can be concluded that the direct effect of sales growth on firm value is greater than the indirect effect through profitability. The results of this analysis illustrate that sales growth used by companies as a benchmark for profitability is not able to have a better impact on achieving corporate value compared to the direct impact of sales growth on firm value. In this study sales growth is not able to mediate profitability because during the research period sales 
growth did not increase. The findings of this study point to the fact that an increase in sales growth has decreased causing the value of the company to decline without first seeing an increase in profitability in the cosmetics subsector manufacturing companies and household needs.

\section{CONCLUSION}

Grounded by the results and the discussion explained above, thus, it can be concluded that first, capital structure has a positive and significant effect on profitability. This means that funding decisions using higher debt can increase the profitability of cosmetics sub-sector manufacturing companies and household needs on the Indonesia Stock Exchange. The second, sales growth has a negative effect and does not significantly affect profitability. This means that sales are not able to increase the profitability of the cosmetics sub-sector manufacturing companies and household needs. The third, capital structure has a positive and significant effect on firm value. This means that funding decisions in the use of high debt can increase the value of the company in the cosmetics sub-sector manufacturing companies and household needs. The fourth, sales growth has a positive and significant effect on firm value. This means that increased sales growth can affect the value of companies and companies that grow rapidly and rely on more debt to give important attention to investors as a perception and indicator that the company has a high risk that affects the decline in corporate value. The fifth, profitability has a positive and significant effect on firm value. This means that profitability is able to influence the value of a company with high debt usage, illustrating good financial performance accompanied by a high risk impact within the company, which provides information to investors. The sixth, the capital structure is able to mediate the value of the company through profitability. This means that the capital structure is able to influence the value of the company through profitability in funding decisions using high debt is not able to affect the value of the company through profitability. The last, sales growth is not able to mediate corporate value through profitability. This means that the growth in asset sales used by companies as a benchmark for increasing profitability is not able to have a better impact on achieving corporate value compared to the direct impact of sales growth on company value.

\section{REFERENCES}

Berita Industri. (2018). Retrieved from https:// kemenperin.go.id/

Brigham, E. F., \& Houston, J. F. (2001). Manajemen Keuangan (Edisi 2). Jakarta: Erlangga.

Chowdhury, A., \& Paul Chowdhury, S. (2010). Impact of Capital Structure on Firm's Value: Evidence from Bangladesh. Business and Economic Horizons, 3, 111-122. https:// doi.org/10.15208/beh.2010.32

Dery, A. P. (2014). Pengaruh Struktur Modal dan Pertumbuhan Perusahaan Tehadap Profitabilitas dan Nilai Perusahaan pada Perusahaan Property Dan Real Estate di Bursa Efek Indonesia. Universitas Warmadewa.

Dewi, D. A. I. Y. M., \& Sudiartha, G. M. (2017). Pengaruh Profitabilitas, Ukuran Perusahaan, dan Pertumbuhan Aset Terhadap Struktur Modal dan Nilai Perusahaan. E-Jurnal Manajemen, 6(4), 2222-2252. Retrieved from https://ojs.unud.ac.id/index.php/ Manajemen/article/view/28486

Dhani, I. P., \& Utama, A. . G. S. (2017). Pengaruh Pertumbuhan Perusahaan, Struktur Modal, dan Profitabilitas Terhadap Nilai Perusahaan. Jurnal Riset Akuntansi Dan Bisnis Airlangga, 2(1). https:// doi.org/10.31093/jraba.v2i1.28

Djazuli, A., Choiriyah, C., \& Anggraini, N. S. (2019). The Impact of Company Size, Asset Structure and Profitability on Capital Structure of the Automotive Sector Companies Listed in Indonesia Stock Exchange. Journal of Management Research, 11(2), 55. https://doi.org/10.5296/ jmr.v11i2.14473

Dramawan, I. D. K. A. (2015). Pengaruh Risiko Keuangan dan Pertumbuhan Penjualan pada Profitabilitas dan Nilai Perusahaan Property. Buletin Studi Ekonomi, 20(2), 83-176. Retrieved from https://ojs.unud.ac.id/ index.php/bse/article/view/18840

Fibriyanto, D. (2015). Analisis Pengaruh Struktur Modal Terhadap Nilai Perusahaan Property dan Realestate yang Listing di Bursa Efek Indonesia Tahun 2009-2011. Jurnal Administrasi Bisnis, 27(2), 1-8. Retrieved from http:// administrasibisnis.studentjournal.ub.ac.id/ index.php/jab/article/view/1116

Hamidah, H., Iswara, D., \& Mardiyati, U. (2016). The Effect of Profitability, Liquidity, Growth Sales, Operating Leverage and Tangibility on Capital Structure (Evidence from Manufacture Firm Listed on Indonesia Stock Exchange in 2011- 2014). JRMSI Jurnal Riset Manajemen Sains Indonesia, 7 (1), 96-116. https://doi.org/10.21009/ JRMSI.007.1.06

Hartono, J. (2013). Teori Portofolio dan Analisis Investasi Edisi 8. Yogyakarta: BPFE. 
Hatta, A. J. (2002). Faktor-Faktor Yang Mempengaruhi Kebijakan Deviden: Investigasi Pengaruh Teori Stakeholder. Jurnal Akuntansi Dan Auditing Indonesia (JAAI), 6(2), 1-22. Retrieved from https:// journal.uii.ac.id/JAAI/article/view/853

Hermuningsih, S. (2012). Pengantar Pasar Modal Indonesia. Yogyakarta: UPP STIM YKPN.

Kesuma, A. (2009). Analisis Faktor yang Mempengaruhi Struktur Modal Serta Pengaruhnya Terhadap Harga Saham Perusahaan Real Estate yang Go Public di Bursa Efek Indonesia. Jurnal Manajemen Dan Kewirausahaan, 11(1), 38-45. https:// doi.org/https://doi.org/10.9744/ jmk.11.1.pp.\%2038-45

Kusumajaya, D. K. O. (2011). Pengaruh Struktur Modal dan Pertumbuhanperusahaan Terhadap Profitabilitas dan nilai Perusahaan pada Perusahaanmanufaktur di Bursa Efek Indonesia (Universitas Udayana). Retrieved from https:// www.academia.edu/7689418/

PENGARUH STRUKTUR MODAL DA N_PERTUMB̄UHAN_PERŪSAHAAN̄_TE R $\bar{H}$ ADAP PROFITA $\bar{B}$ ILITAS DAN NIL AI PERUSA N_MANUFAKTUR_DI_BURSA_EFEK_I NDONESIA

Limbong, D. T. S., \& Chabachib, M. (2016). Analisis Pengaruh Struktur Modal, Pertumbuhan Penjualan, dan Ukuran Perusahaan Terhadap Nilai Perusahaan dengan Profitabilitas Sebagai Variabel Intervening (Studi Kasus Pada Perusahaan Real Estate dan Properti yang Terdaftar di BEI Tahun 2010-2014). Diponegoro Journal of Management, 5(4), 62-75. Retrieved from https://ejournal3.undip.ac.id/index.php/ djom/article/view/17880

Machfoedz, M. (2008). Akuntansi Manajemen Perencanaan dan Pembuatan Keputusan Jangka Pendek (E. ke 5, Ed.). Yogyakarta: STIE-Widya Wiwaha.

Margaretha, F. (2011). Manajemen Keunagan untuk Manajer Non Keuangan. Jakarta: Erlangga.

Marlina, M., Pinem, D., \& Hidayat, N. F. (2020). Effect of Liquidity, Profitability, and Sales Growth on Capital Structure (in Manufacturing Companies). International Humanities and Applied Science Journal, 3 (2), 1-10. https://doi.org/10.22441/ ihasj.2020.v3i2.01

Murhadi, W. R. (2008). Studi Kebijakan Deviden: Anteseden dan Dampaknya Terhadap Harga Saham. Jurnal Manajemen Dan Kewirausahaan, 10(1), 1-17. https://doi.org/ https://doi.org/10.9744/jmk.10.1.pp.\%20117

Pantow, M. S. R., Murni, S., \& Trang, I. (2015). Analisa Pertumbuhan Penjualan, Ukuran Perusahaan, Return on Asset, dan Struktur
Modal Terhadap Nilai Perusahaan yang Tercatat di Indeks LQ 45. Jurnal EMBA: Jurnal Riset Ekonomi, Manajemen, Bisnis Dan Akuntansi, 3(1), 961-971. https:// doi.org/https://doi.org/10.35794/ emba.3.1.2015.7801

Puspita, N. S. (2011). Analisis Pengaruh Struktur Modal, Pertumbuhan Penjualan, dan Ukuran Perusahaan Terhadap Nilai Perusahaan dengan Profitabilitas sebagai Variabel Intervening (Studi Kasus Pada Perusahaan Real Estate dan Properti yang Terdaftar di Bei Tahun 2010-2014). Universitas Diponegoro.

Putri, I. G. A. P. T. (2020). Effect of Capital Structure and Sales Growth on Firm Value with Profitability as Mediation. International Research Journal of Management, IT and Social Sciences, 7(1), 145-155. https:// doi.org/10.21744/irjmis.v7n1.833

Salvatore, D. (2005). Ekonomi Manajerial dalam Perekonomian Global. Jakarta: Salemba Empat.

Sari, P. I. P., \& Abundanti, N. (2014). Pengaruh Pertumbuhan Perusahaan dan Leverage Terhadap Profitabilitas dan Nilai Perusahaan. E-Jurnal Manajemen, 3(5), 1427-1441. Retrieved from https:// ojs.unud.ac.id/index.php/Manajemen/article/ view/7863

Sartono, A. (2001). Manajemen Keuangan Teori dan Aplikasi (Edisi 2). Yogyakarta: BPFE.

Sartono, A. (2012). Manajemen Keuangan Teori dan Aplikasi (Edisi 4). Yogyakarta: BPFE.

Shubita, M. F., \& Alsawalhah, J. M. (2012). The Relationship between Capital Structure and Profitability. International Journal of Business and Social Science, 3(16), 104112. Retrieved from https:// citeseerx.ist.psu.edu/viewdoc/download? doi $=10.1 \cdot 1.1052 .655 \&$ rep $=$ rep1\&type $=$ pdf

Subramanyam, K. R., \& Wild, J. J. (2014). Financial Statement Analysis 10th edition (Ed. 10). New York: McGraw-Hill/Irwin.

Ugwuanyi, U. (2012). Capital Structure and Market Values of Companies. European Journal of Business and Management, 4(21), 49-54. Retrieved from https://www.iiste.org/ Journals/index.php/EJBM/article/view/3616

Wiagustini, N. L. P. (2010). Dasar-Dasar Manajemen Keuangan. Denpasar: Udayana University Press.

Widarjo, W., \& Setiawan, D. (2009). Pengaruh Rasio Keuangan Terhadap Kondisi Financial Distress Perusahaan Otomotif. Jurnal Bisnis Dan Akuntansi, 11(2), 107-119. Retrieved from https://jurnaltsm.id/index.php/JBA/ article/view/174 